\title{
Musculoskeletal complaints in patients with Familial Mediterranean Fever
}

\author{
ZB Özçakar, S Şahin-Kunt, S Özdel, F Yalçınkaya* \\ From 8th International Congress of Familial Mediterranean Fever and Systemic Autoinflammatory Diseases \\ Dresden, Germany. 30 September - 3 October 2015
}

\section{Question}

Familial Mediterranean fever (FMF) is an autosomal recessive disease, characterised by recurrent, self limited attacks of fever with serositis. The aim of our study was to describe the frequency of musculoskeletal complaints in children with FMF and investigate the effect of genotype on these findings.

\section{Methods}

Files of patients who had been seen in our department (during routine follow-up visits) between January 2013 and January 2014 were retrospectively evaluated. Patients with two mutations were divided into 3 groups; M694V/ M694V, M694V/Other mutation and patients carrying two mutations other than M694V. Patients with one mutation were divided into 2 groups; M694V and non M694V carriers.

\section{Results}

The study group comprised 317 FMF patients (170 females, 147 males) with a mean age of $12.2 \pm 5.7$ years. The frequency of musculoskeletal complaints were as follows; arthritis $18 \%$, arthralgia $43 \%$, leg pain $43 \%$, heel pain $36 \%$, myalgia $8 \%$, protracted arthritis $2 \%$, protracted febrile myalgia $2 \%$. Leg pain and heel pain were more frequently detected in patients with homozygous M694V ( $<<0.05)$. Among patients with heterozygous mutations; children with M694V mutation had more frequently artralgia, leg pain and heel pain $(\mathrm{p}<0.05)$.

\section{Conclusions}

Musculoskeletal problems were common complaints in patients with FMF. Genotype seems to effect the frequency of these problems and M694V mutation is a predisposing factor for musculoskeletal complaints.

Ankara University, Pediatric Rheumatology, Ankara, Turkey
Published: 28 September 2015

doi:10.1186/1546-0096-13-S1-P85

Cite this article as: Özçakar et al:: Musculoskeletal complaints in patients with Familial Mediterranean Fever. Pediatric Rheumatology 2015 13(Suppl 1):P85.
Submit your next manuscript to BioMed Central and take full advantage of:

- Convenient online submission

- Thorough peer review

- No space constraints or color figure charges

- Immediate publication on acceptance

- Inclusion in PubMed, CAS, Scopus and Google Scholar

- Research which is freely available for redistribution
() Biomed Central 